\title{
Evaluation of anti-obesity potential of aqueous extract of Achyranthes aspera Linn. in high fat diet induced obese rats
}

\author{
Kumaraswamy Athesh ${ }^{1 *}$, Rangaraju Sivasubramanian ${ }^{1}$, Gnanasekaran Jothi ${ }^{1}$ and Pemiah Brindha ${ }^{2}$
}

\begin{abstract}
Background: Obesity, reached epidemic proportions globally is often associated with life threatening comorbidities. The unavailability of safe and effective long term medications for obesity in modern pharmacotherapy forces the scientific community to explore the potential of Ayurvedic traditional healers as they are considered safe and effective.

Objective: To explore the anti-obesity potential of aqueous extract of aerial parts of Achyranthes aspera L. (AEAA), a traditional healer in high fat diet (HFD) induced obese rats.

Methods: AEAA was prepared and subjected to in-vitro pancreatic lipase inhibition assay and in-vivo anti-obesity studies. For in-vivo studies, HFD fed obese prone Wistar albino rats were divided into five experimental groups (Group II to VI): animals fed with standard pellet chow served as normal control (Group I) while, animals continued with HFD alone served as obese control (Group II); Group III, IV and V were administered AEAA at a dose of 100, $200 \mathrm{and} 300 \mathrm{mg} /$ $\mathrm{kg}$ b.w. respectively along with HFD; and animals administered orlistat (30 mg/kg bw) along with HFD served as standard control (Group VI). All the drugs were administered orally once a day for a period of 60 days. At the end of the experimental period various physical, biochemical and histopathological observations were made.

Results: In-vitro studies showed AEAA partially but not significantly inhibited the activity of pancreatic lipase. Data of in-vivo studies revealed, significant reduction in body weights, fat pad weights and organ weights upon AEAA treatment. Elevated levels of glucose, insulin, leptin, lipid profiles and antioxidant status were also brought back to normal.
\end{abstract}

Conclusion: The obtained results clearly suggested that AEAA possess pronounced anti-obesity potential.

Keywords: Obesity, High fat diet, Pancreatic lipase, Leptin, Antioxidant, Achyranthes aspera L

\section{Introduction}

Obesity is a chronic, multifactorial medical condition characterized by excess body fat that develops as a result of long-term energy imbalance i.e., excessive caloric consumption and insufficient energy output. This extra energy gets accumulated in the form of adipose tissue. Body mass index (BMI), a measurement based on weight and height, defines people as overweight when their

\footnotetext{
* Correspondence: athesh.biosearch@gmail.com

${ }^{1} \mathrm{PG} \&$ Research Department of Biochemistry, Srimad Andavan Arts and Science College (Autonomous), Affiliated to Bharathidasan University, Tiruchirappalli, Tamil Nadu 620 005, India

Full list of author information is available at the end of the article
}

BMI is between $25 \mathrm{~kg} / \mathrm{m}^{2}$ and $30 \mathrm{~kg} / \mathrm{m}^{2}$, and obese when it is greater than $30 \mathrm{~kg} / \mathrm{m}^{2}$ [1]. This accumulation of excess body fat have adverse effects on health, as obese having the highest risk for the development of several life-threatening diseases including hypertension, coronary heart disease, type 2 diabetes, gallbladder disease, and various forms of cancer in addition to some other non-fatal conditions like back pain, arthritis, infertility and poor psychosocial functioning. The statistics says 'worldwide prevalence of overweight and obesity has tripled since 1975' and nearly one third of the world's population is now classified as overweight or obese. As

\section{Springer Open}

(๑) The Author(s). 2020 Open Access This article is licensed under a Creative Commons Attribution 4.0 International License, which permits use, sharing, adaptation, distribution and reproduction in any medium or format, as long as you give appropriate credit to the original author(s) and the source, provide a link to the Creative Commons licence, and indicate if changes were made. The images or other third party material in this article are included in the article's Creative Commons licence, unless indicated otherwise in a credit line to the material. If material is not included in the article's Creative Commons licence and your intended use is not permitted by statutory regulation or exceeds the permitted use, you will need to obtain permission directly from the copyright holder. To view a copy of this licence, visit http://creativecommons.org/licenses/by/4.0/. 
obesity is increasing as global epidemic in all age groups irrespective of geographical locality, ethnicity or socioeconomic status [2], intervention for its prevention and treatment are urgently needed. There are so many approaches are followed currently to control overweight and obesity such as lifestyle modification, including dieting and physical exercise to shed extra calorie, antiobesity drugs to reduce appetite or inhibit fat absorption and bariatric surgery to earlier satiation and reduce ability to absorb nutrients from food [3]. But all these interventions have very modest efficacy in bringing weight loss. Pharmacotherapy of obesity will only be effective if the medications are continued indefinitely. But orlistat alone is currently approved for long term use by the FDA [4], which is also reported to have adverse side effects such as steatorrhea, flatus, fecal incontinence, oily spotting, constipation etc. [5]. Hence, there is a clear need for alternate sources of drugs and strategies to treat obesity. There are many remedies been given in an Ayurvedic treatise Shushruta Samhita for treating 'medroga' (obesity). Herbs are always been the principle form of medicine in India and presently they are becoming popular throughout the world because of their safety, efficacy, holistic approach and cultural acceptability. Thus scientifically exploring the anti-obesity potential of traditional healers may pave way to find novel drugs to manage obesity.

Achyranthes aspera Linn, (Family: Amaranthaceae), commonly known as Prickly chaff flower in English, and Nayuruvi in Tamil is an erect, perennial herb, found on road sides, field boundaries and waste places as a weed throughout India up to an altitude of $2100 \mathrm{~m}$. It is widely used in traditional system of medicine as purgative, laxative, liver complaints, rheumatism, scabies and other skin diseases. The plant is also well known for its spermicidal, hypoglycemic, hepatoprotective, anti-inflammatory, analgesic, antipyretic and antiarthritic activity [6, 7]. In traditional medicine (Ayurvedic Pharmacopeia) it has been mentioned to treat medroga [6]. But no systematic studies have been reported in its aqueous extract for antiobesity activity. Therefore, the present study has been designed to evaluate the anti-obesity potential of aqueous extract of aerial parts of Achyranthes aspera L. (AEAA) in rats fed with high fat diet thereby providing scientific evidence to this traditional healer (Fig. 1).

\section{Materials and methods}

\section{Collection and authentication of plant material}

Fresh aerial parts of Achyranthes aspera L. were collected from in and around Tiruchirappalli, South India and was identified with the help of Flora of Presidency of Madras [8] and was confirmed and authenticated by comparing with the herbarium specimen deposited at RAPINAT Herbarium, St.Joseph's College, Tiruchirappalli, Tamil Nadu, India. \{Voucher Specimen Number: Achyranthes aspera L. - RHT (Acc.): 3676\}.

\section{Preparation of aqueous plant extract}

After proper identification, the selected

plant material was cleaned, shade dried and coarsely powdered. The granulated powder was then mixed thoroughly with six times the volume of water, boiled and stirred continuously until the volume reduced to $1 / 3$ rd. The extract was then filtered using muslin cloth and the filterate was evaporated in a water bath till it reaches a thick paste consistency [9]. Paste form of the extract

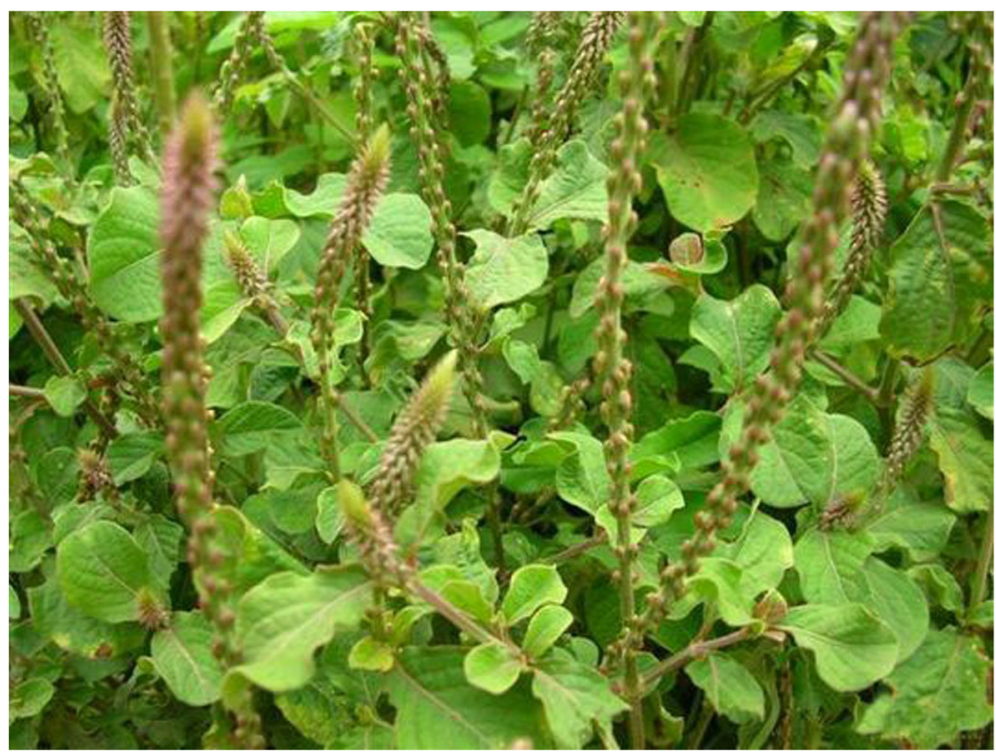

Fig. 1 Achyranthes aspera Linn. (Aerial parts) 
obtained was stored in an airtight container at $4{ }^{\circ} \mathrm{C}$. The extractive efficiency of aqueous extract was found to be $27.3 \% \mathrm{~W} / \mathrm{W}$. Pancreatic lipase inhibition assay [10], determination of plasma triacylglycerol after oral administration of lipid emulsions to rats [11] and in-vivo antiobesity studies were then carried out using this extract.

\section{Experimental animals}

Healthy adult Wistar strain male albino rats weighing around 100-125 g obtained from Tamil Nadu Veterinary and Animal Sciences University, Chennai, India were used for this study. The animals were housed in polypropylene cages under controlled environment $(12: 12-\mathrm{h}$ light/ dark cycle; an ambient temperature of $23 \pm 2{ }^{\circ} \mathrm{C}$ with $65 \pm 5 \%$ humidity) with free access to standard rat chow pellet (obtained from Sai Durga Foods and Feeds, Bangalore, India) and water ad libitum. The animals were acclimatized to the laboratory conditions for a week before experiments.

\section{Preparation of high fat diet (HFD)}

The HFD consists of beef tallow - 35\% (315 kcal), casein - 20\% (80 kcal), corn starch - 15\% (60 kcal), sucrose $20 \%$ (80 kcal), corn oil - 5\% (45 kcal), mineral mixture $4 \%$ and vitamin mixture $-1 \%[11,12]$. The dietary ingredients were homogenized in warm distilled water and pellets were prepared. These pellets were dried in hot air oven before feeding. The diets were prepared freshly once in a week. The diet was prepared in such a way that fat accounted for around $62 \%$ of the total energy values of the HFD, while carbohydrates accounted for $24 \%$ and proteins for $14 \%$. The energy content was calculated on the basis of $9 \mathrm{kcal} / \mathrm{g}$ for fat, $4 \mathrm{kcal} / \mathrm{g}$ for carbohydrate and $4 \mathrm{kcal} / \mathrm{g}$ for protein [13].

\section{Induction of obesity}

A group of 40 male Wistar albino rats weighing 100$125 \mathrm{~g}$ were selected and obesity was induced in them by feeding the HFD for a period of 45 days. After the induction period, 30 animals weighing around $225-250 \mathrm{~g}$ (considered obese prone) were selected for anti-obesity studies [14]. Another 6 animals fed with normal pellet chow were used as normal control.

\section{Experimental design}

The HFD fed obese prone Wistar albino rats were divided into 5 groups with 6 rats each, while the normal diet fed 6 animals served as normal control group.

Group I: Normal control - rats fed with normal pellet chow.

Group II: Obese control - rats fed with HFD.

Group III: Rats fed with HFD + Treated with AEAA (100 mg/kg b.w).
Group IV: Rats fed with HFD + Treated with AEAA (200 mg/kg b.w).

Group V: Rats fed with HFD + Treated with AEAA (300 mg/kg b.w).

Group VI: Rats fed with HFD + Treated with $30 \mathrm{mg} / \mathrm{kg}$ b.w of orlistat (purchased as $60 \mathrm{mg}$ capsules from Vasan Medical Hall, Tiruchirappalli, India).

Therapeutic doses are selected based on reviews of acute toxicity studies, which revealed that aqueous extract of Achyranthes aspera L. did not show any signs or symptoms of toxicity or mortality upto the dose of 2000 $\mathrm{mg} / \mathrm{kg}$ [15]. So, doses around $1 / 10^{\text {th }}$ of $2000 \mathrm{mg} / \mathrm{kg}$ (i.e., 100,200 and $300 \mathrm{mg} / \mathrm{kg} \mathrm{bw}$ ) were selected for the present study.

All the drugs were given once a day orally for a period of 60 days $[16,17]$ along with HFD. At the end of the experimental period the animals were sacrificed by cervical dislocation. The blood was collected for biochemical analysis. The liver, kidney, heart, spleen and fat pads (mesenteric, perirenal and retroperitoneal) were dissected out, washed in $0.9 \%$ ice cold saline, blotted dry with a paper towel, weighed quickly and processed for further studies. Liver tissues were homogenized in $0.1 \mathrm{M}$ phosphate buffer ( $\mathrm{pH}$ 7.4) and used for antioxidant analysis and histopathological studies.

\section{Determination of anti-obesity potential Measurement of food intake}

Food intake was measured every day throughout the experimental period. It was determined by measuring the difference between the pre-weighed chows and weight of the chow that remained every $24 \mathrm{~h}$ per cage basis [18].

\section{Body weight of the animals}

Body weights of the experimental animals were recorded at the beginning of the study and 10 days once thereafter until the experimental period using the rough table top balance.

\section{Determination of adipocyte size (area)}

The areas of adipocytes were measured using Nikon (Eclipse, Ci) trinocular light microscope with NIS digital imaging software. The measurements were made after the calibration of the microscope using standard micrometre supplied by Nikon.

\section{Determination of body mass index (BMI) and waist circumference (WC)}

The BMI was calculated using the formula [19], BMI = Body Weight (g)/Length $\left(\mathrm{cm}^{2}\right)$.

Body length (nose-to-anus length) of the experimental animals was measured on day 1 and the final day (60th day) of plant drug treatments, under mild anaesthesia ( $0.1 \mathrm{ml}$ i.p. of $1 \%$ sodium barbiturate). WC was measured 
on the largest zone of the rat abdomen using a plastic non extensible measuring tape by keeping the rats in ventral position under mild anaesthesia.

\section{Determination of other biochemical parameters}

Biochemical parameters such as Glucose [20], Insulin [21], Leptin [22], Triglycerides [23], Free Fatty Acids [24], Cholesterol [25], HDL Cholesterol [26], Lipid Peroxides (LPO) [27], Reduced Glutathione (GSH) [28], Glutathione Peroxidase (GPx) [29], Superoxide Dismutase (SOD) [30] and Catalase [31] were estimated and or assayed by using standard procedures.

The LDL and VLDL-Cholesterol were determined by using the following Friedewald formula [26]:

$$
\begin{aligned}
\mathrm{LDL}-\text { Cholesterol } & =\text { Total Cholesterol } \\
& -\{\text { HDL }-\mathrm{C}-(\text { Triglyceride } / 5)\}
\end{aligned}
$$$$
\text { VLDL }- \text { Cholesterol }=\text { Total Serum Triglyceride } / 5
$$

Atherogenic index (AI) was calculated by using the following formula [32]:

$$
\mathrm{AI}=\frac{\text { Total Cholesterol }}{\text { HDL-Cholesterol }}
$$

\section{Statistical analysis}

All the data were expressed as mean \pm S.E.M. The data were analysed using the SPSS statistics programme by one-way analysis of variance (ANOVA) followed by Duncan's multiple range test. Inter group comparison were carried out and a $P$ value of $<0.05$ was considered statistically significant.

\section{Results}

\section{Effect of AEAA on in-vitro pancreatic lipase inhibition} activity

The AEAA was studied for its in-vitro pancreatic lipase inhibitory activity and the effect was compared with standard drug Orlistat. The obtained results were shown in Fig. 2. AEAA shown inhibition in pancreatic lipase $\left(\mathrm{IC}_{50}-417.54 \mu \mathrm{g} / \mathrm{ml}\right)$ activity but not significant level when compared to Orlistat $\left(\mathrm{IC}_{50}-36.23 \mu \mathrm{g} / \mathrm{ml}\right)$.

Effect of AEAA on plasma triacylglycerol (TAG) levels after Oral Administration of Lipid Emulsions (LE) to rats

Figure 3 reveals serial changes in plasma TAG concentration when LE was administered with or without test drug AEAA and standard drug Orlistat. The plasma TAG level gets elevated at 1,2 and $3 \mathrm{~h}$ interval and get started decreasing after that when LE alone was supplied to the animals. LE along with various doses of AEAA administration, shown slight decreases in the levels of elevated plasma TAG when compared to control (LE alone) group in a dose dependent manner. But the effect of AEAA was not comparable to that of Orlistat, the standard drug which shown much better effect.

\section{Effect of AEAA on daily food intake}

The daily food intake of experimental rats was measured and the obtained results were presented in Fig. 4 in the form of average food intake. The data revealed slight decrease in daily food intake of AEAA treated animals when compared to food intake of obese control ie., HFD alone fed animals.

\section{Effect of AEAA on body weight}

The initial body weight of the experimental rats were recorded on day 1 and then changes in their body weight on treatment with AEAA were recorded at a regular interval of 10 days and the data obtained were graphically represented in Fig. 5. The obtained data clearly shows significant reduction in the body weight of the obese rats in a dose dependent manner when treated with different dose levels (100, 200 and $300 \mathrm{mg} / \mathrm{kg} \mathrm{bw}$ ) of AEAA.

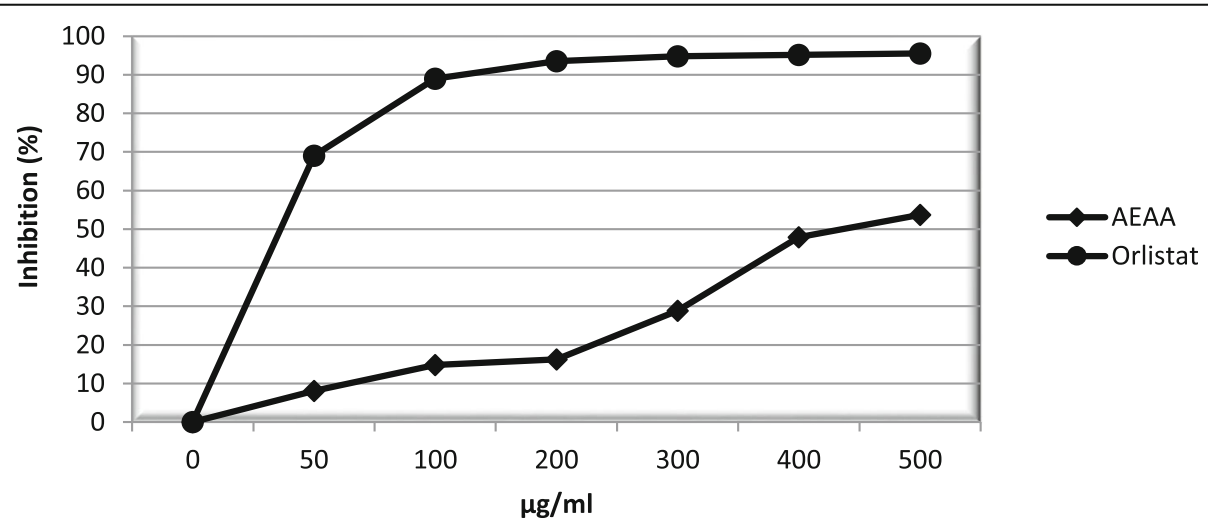

Fig. 2 The inhibitory effect of AEAA on Pancreatic Lipase activity; values are mean of 4 experiments; AEAA - Aqueous Extract of Achyranthes aspera $\mathrm{L}$ 


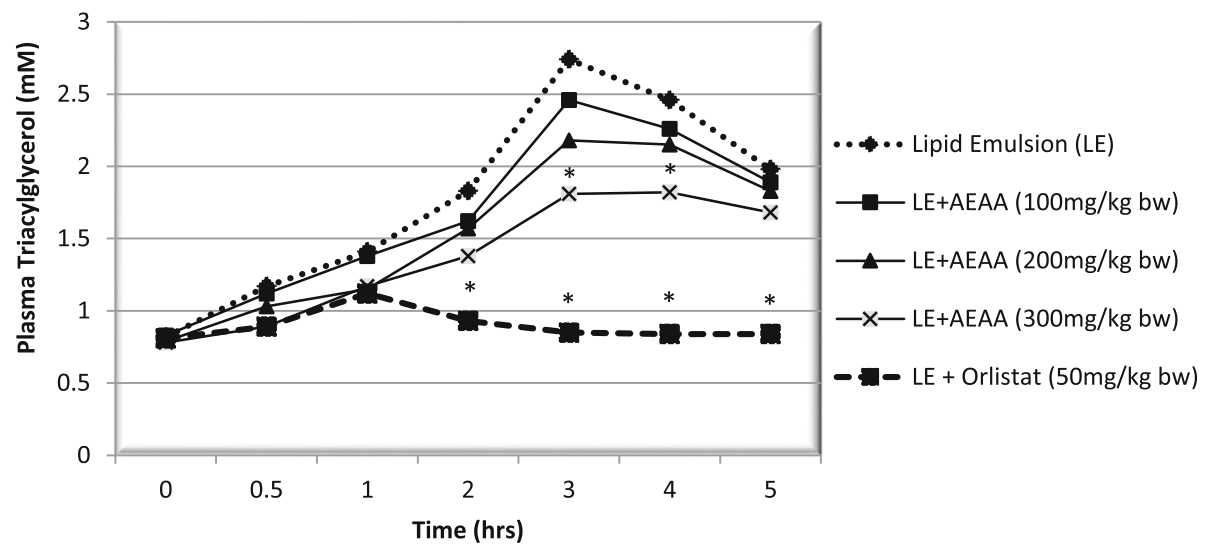

Fig. 3 Plasma triacylglycerol levels after oral administration of lipid emulsions to rats; values are mean of 6 rats; * $p<0.05$, significantly different from lipid emulsion only treated group; LE - Lipid Emulsion; AEAA - Aqueous Extract of Achyranthes aspera L.

\section{Effect of AEAA on fat pad weight, adipocyte size and} organ weight

The various fat pad weights (mesenteric, retroperitoneal and perirenal white adipose tissue) adipocyte size and various organ weights were found to be elevated in HFD fed obese control rats but were reduced significantly after treatment with AEAA in a dose dependent manner (Table 1).

\section{Effect of AEAA on body mass index (BMI) and waist circumference (WC)}

The BMI and WC of the experimental animals were calculated on first and final day of the experiments and the values were represented in Table 2 . The AEAA treatment efficiently reduced the BMI and WC of the obese rats when compared to obese control rats and the effect was found to be dose dependent.
Effect of AEAA on levels of blood glucose, serum insulin, Leptin and lipid profiles

The effect of AEAA on blood glucose, serum insulin, leptin and lipid profile of experimental rats were shown in Table 3. Administration of HFD to the experimental rats resulted in the elevation of blood glucose, serum insulin, leptin, triglyceride, total cholesterol (TC), LDLcholesterol (LDL-C), VLDL-cholesterol (VLDL-C) and atherogenic index (AI) while HDL-cholesterol (HDL-C) was found to be decreased. Oral administration of different dose levels of AEAA to the obese rats efficiently restored these biochemical parameters to near normal in a dose dependent manner.

Effect of AEAA on hepatic and cardiac lipid profile

The effect of treatment of experimental rats with AEAA on hepatic and cardiac lipid profile was shown in Table 4. The elevated levels of hepatic as well as cardiac

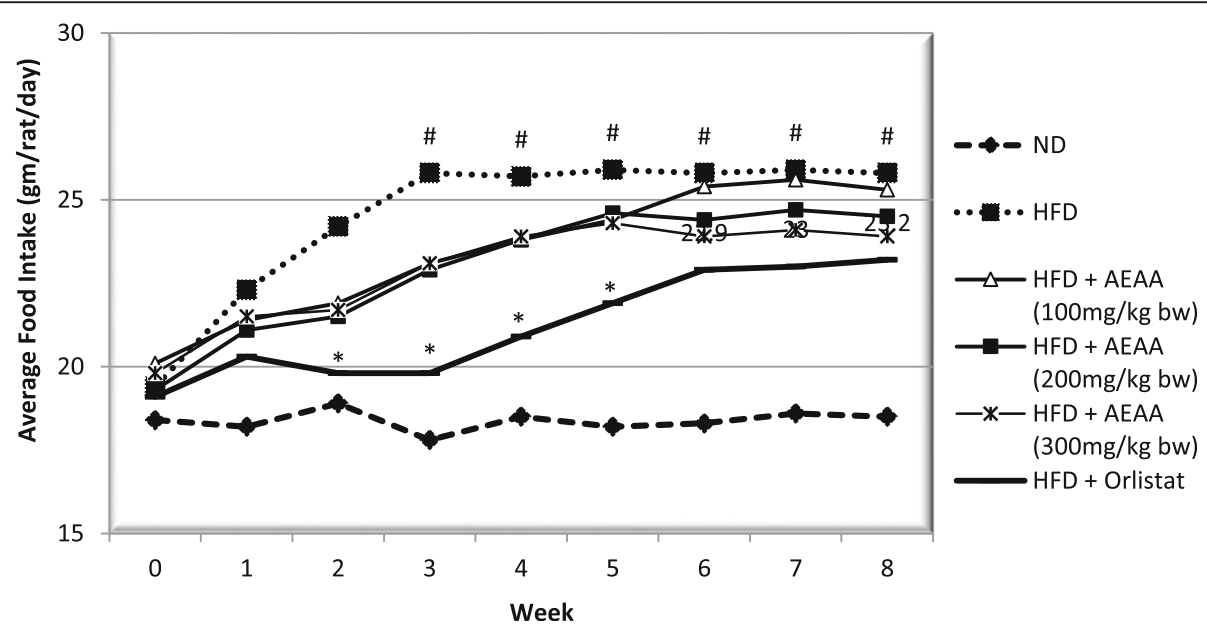

Fig. 4 Levels of Daily Food Intake in experimental rats; values are mean of 6 rats; ${ }^{*} p<0.05$, significantly different from ND fed group; ${ }^{*} p<0.05$, significantly different from HFD administered group; AEAA - Aqueous Extract of Achyranthes aspera L.; ND - Normal Diet; HFD - High Fat Diet 


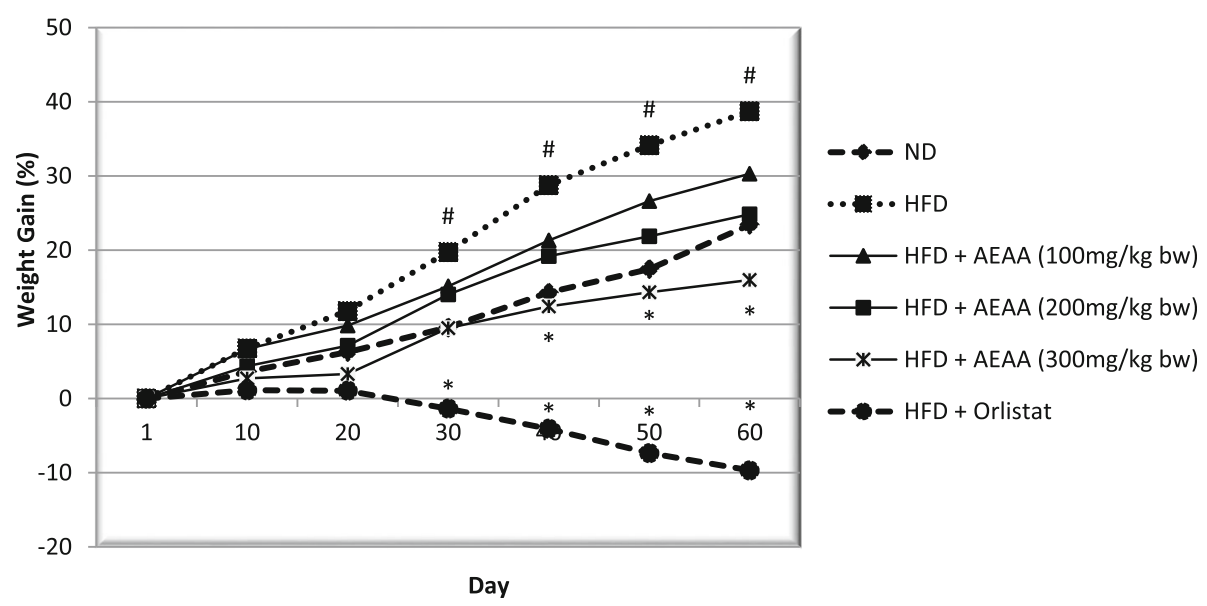

Fig. 5 Percentage Body Weight Gain in experimental rats; values are mean of 6 rats; ${ }^{*} p<0.05$, significantly different from ND fed group; * $p<0.05$, significantly different from HFD administered group; AEAA - Aqueous Extract of Achyranthes aspera L.; ND - Normal Diet; HFD - High Fat Diet

triglyceride and cholesterol in the HFD fed rats were normalised on treatment with AEAA.

\section{Effect of AEAA on enzymatic and non-enzymatic anti- oxidant status}

The effects of treatment of obese rats with AEAA on enzymatic and non-enzymatic anti-oxidant status in hepatic tissues were given in Table 5 .

The observed data showed that the elevated levels of lipid peroxide (LPO) were significantly decreased on treatment with test drug, AEAA. Glutathione (GSH) contents depleted in the rats with obesity induced by HFD were also restored after treatment. The data also showed that the activities of enzymatic antioxidants like Glutathione peroxidase (GPx), Superoxide Dismutase (SOD) and Catalase (CAT) were decreased in HFD group, while test drug administration significantly increased the activities of such antioxidant enzymes in liver in dose dependent manner.

\section{Histopathological studies}

The liver histological observations revealed large fat droplets throughout the liver lobules of HFD group animals (Fig. 6), whereas after treatment with test drug AEAA, the fat droplets were disappeared in the high dose $(300 \mathrm{mg} / \mathrm{kg} \mathrm{bw})$ treated group animals. In histological photograph of adipose tissue, the sizes of retroperitoneal adipocyte appeared to be larger in the HFD group than the normal control group, whereas, in AEAA and orlistat treated groups the size of the adipose tissue appeared smaller than in the HFD group (Fig. 7).

Table 1 Fat Pad Weights, Adipocyte Size and Organ Weights of Experimental Rats

\begin{tabular}{|c|c|c|c|c|c|c|}
\hline Experimental Groups & Group I & Group II & Group III & Group IV & Group V & Group VI \\
\hline Mesenteric WAT (g) & $\begin{array}{l}3.38 \\
\pm 0.32\end{array}$ & $\begin{array}{l}12.76 \\
\pm 0.41^{\#}\end{array}$ & $\begin{array}{l}10.15 \\
\pm 0.9\end{array}$ & $\begin{array}{l}9.14 \\
\pm 0.9\end{array}$ & $\begin{array}{l}8.28 \\
\pm 0.25^{*}\end{array}$ & $\begin{array}{l}4.09 \\
\pm 0.25^{* *}\end{array}$ \\
\hline Retro-peritoneal WAT (g) & $\begin{array}{l}4.83 \\
\pm 0.18\end{array}$ & $\begin{array}{l}14.65 \\
\pm 0.55^{\#}\end{array}$ & $\begin{array}{l}12.62 \\
\pm 0.48\end{array}$ & $\begin{array}{l}10.25 \\
\pm 0.31\end{array}$ & $\begin{array}{l}9.86 \\
\pm 0.33^{*}\end{array}$ & $\begin{array}{l}5.26 \\
\pm 0.23 * *\end{array}$ \\
\hline Perirenal WAT (g) & $\begin{array}{l}0.68 \\
\pm 0.07\end{array}$ & $\begin{array}{l}4.21 \\
\pm 0.18^{\#}\end{array}$ & $\begin{array}{l}4.03 \\
\pm 0.11\end{array}$ & $\begin{array}{l}3.52 \\
\pm 0.15\end{array}$ & $\begin{array}{l}2.53 \\
\pm 0.05^{*}\end{array}$ & $\begin{array}{l}0.93 \\
\pm 0.03 * *\end{array}$ \\
\hline Adipocyte Size (Area - $\mu m^{2}$ ) & $\begin{array}{l}29,605.66 \\
\pm 3967\end{array}$ & $\begin{array}{l}87,868.06 \\
\pm 8121^{\#}\end{array}$ & $\begin{array}{l}77,476.05 \\
\pm 7698\end{array}$ & $\begin{array}{l}61,075.34 \\
\pm 7072\end{array}$ & $\begin{array}{l}57,441.08 \\
\pm 4479^{*}\end{array}$ & $\begin{array}{l}33,008.04 \\
\pm 6064^{* *}\end{array}$ \\
\hline Liver (g) & $\begin{array}{l}5.35 \\
\pm 0.14\end{array}$ & $\begin{array}{l}9.96 \\
\pm 0.18^{\#}\end{array}$ & $\begin{array}{l}7.68 \\
\pm 0.06\end{array}$ & $\begin{array}{l}6.86 \\
\pm 0.09\end{array}$ & $\begin{array}{l}6.13 \\
\pm 0.11 *\end{array}$ & $\begin{array}{l}5.55 \\
\pm 0.11 * *\end{array}$ \\
\hline Kidney (g) & $\begin{array}{l}1.35 \\
\pm 0.06\end{array}$ & $\begin{array}{l}2.29 \\
\pm 0.08^{\#}\end{array}$ & $\begin{array}{l}1.95 \\
\pm 0.11\end{array}$ & $\begin{array}{l}1.75 \\
\pm 0.03\end{array}$ & $\begin{array}{l}1.53 \\
\pm 0.06^{*}\end{array}$ & $\begin{array}{l}1.34 \\
\pm 0.03 * *\end{array}$ \\
\hline Heart (g) & $\begin{array}{l}0.62 \\
\pm 0.02\end{array}$ & $\begin{array}{l}1.03 \\
\pm 0.06^{\#}\end{array}$ & $\begin{array}{l}0.93 \\
\pm 0.05\end{array}$ & $\begin{array}{l}0.83 \\
\pm 0.03\end{array}$ & $\begin{array}{l}0.74 \\
\pm 0.03^{*}\end{array}$ & $\begin{array}{l}0.63 \\
\pm 0.07 * *\end{array}$ \\
\hline Spleen (g) & $\begin{array}{l}0.53 \\
\pm 0.02\end{array}$ & $\begin{array}{l}0.95 \\
\pm 0.04^{\#}\end{array}$ & $\begin{array}{l}0.78 \\
\pm 0.06\end{array}$ & $\begin{array}{l}0.67 \\
\pm 0.03\end{array}$ & $\begin{array}{l}0.62 \\
\pm 0.05^{*}\end{array}$ & $\begin{array}{l}0.52 \\
\pm 0.04 * *\end{array}$ \\
\hline
\end{tabular}

Values are mean \pm S.E.M of 6 rats; ${ }^{*} p<0.01$ vs Normal Control (Group I); ${ }^{*} p<0.05$ vs Obese Control (Group II); ${ }^{* *} p<0.01$ vs Obese Control (Group II) 
Table $2 \mathrm{BMl}$ and Waist Circumference of Experimental Rats

\begin{tabular}{|c|c|c|c|c|}
\hline \multirow{2}{*}{$\begin{array}{l}\text { Experimental } \\
\text { Groups }\end{array}$} & \multicolumn{2}{|c|}{ Body Mass Index $\left(\mathrm{g} / \mathrm{cm}^{2}\right)$} & \multicolumn{2}{|c|}{ Waist Circumference $(\mathrm{cm})$} \\
\hline & Initial & Final & Initial & Final \\
\hline Group I & $0.51 \pm 0.02$ & $0.5 \pm 0.03$ & $16.4 \pm 2.02$ & $18.9 \pm 1.63$ \\
\hline Group II & $0.51 \pm 0.03$ & $0.65 \pm 0.02^{\#}$ & $21.6 \pm 1.53$ & $26.9 \pm 1.65^{\#}$ \\
\hline Group III & $0.52 \pm 0.04$ & $0.62 \pm 0.02$ & $21.2 \pm 1.09$ & $24.5 \pm 0.52$ \\
\hline Group IV & $0.52 \pm 0.03$ & $0.59 \pm 0.01$ & $21.6 \pm 1.83$ & $23.5 \pm 0.61$ \\
\hline Group V & $0.52 \pm 0.02$ & $0.57 \pm 0.03^{*}$ & $21.1 \pm 1.92$ & $22.4 \pm 0.37^{*}$ \\
\hline Group VI & $0.51 \pm 0.04$ & $0.48 \pm 0.03 *$ & $21.6 \pm 1.53$ & $18.7 \pm 1.22^{*}$ \\
\hline
\end{tabular}

Values are mean \pm S.E.M of 6 rats; ${ }^{\#} p<0.01$ vs Normal Control (Group I); ${ }^{*} p<0.05$ vs Obese Control (Group II)

\section{Discussion}

Obesity is a serious public health concern of twenty-first century as it is growing worldwide in epidemic proportions. This obesity epidemic, alert the public and scientific communities to improve the effectiveness of available treatments. The necessity of safe and long term effective drug for obesity prompted us to scientifically evaluate the anti-obesity potential of aqueous extract of a traditional healer Achyranthes aspera Linn. in high fat diet (HFD) induced obese rats. Among various animal models of obesity, HFD induced animal models are used for this study as a high percentage of fat (particularly beef tallow) in the diet is considered to be an important factor in the development of obesity, with visceral adiposity, hyperglycemia, dyslipidaemia, hyperinsulinemia, and hepatic steatosis, which are distinctly linked with human obesity [33].

It is well known that dietary fat (triacylglycerol) is not directly absorbed from the intestine unless it has been subjected to the action of pancreatic lipase [34]. Since dietary lipids represent the major source of extra calories, the inhibition of fat digestion is an interesting approach for reducing fat absorption. Orlistat is the only authorized pancreatic lipase inhibitor currently available in the market to treat obesity, which works by inhibiting the lipase activity and thereby increasing fat excretion into faeces [35]. But it was also reported that prolonged intake of orlistat have adverse effects such as steatorrhea, bloating, oily spotting, faecal urgency etc. [36]. Thus the search for safe and potent pancreatic lipase inhibitor is still in hunt. In the present study, the plant extract (AEAA) has been analysed for its in-vitro pancreatic lipase inhibition assay and the obtained data shown that AEAA inhibited pancreatic lipase slightly in a dose dependent manner (Fig. 2). To confirm this in-vitro pancreatic lipase inhibition activity, the effect of AEAA was examined on plasma triacylglycerol concentrations after oral administration of a lipid emulsion containing corn

Table 3 Levels of Blood Glucose, Serum Insulin, Leptin and Lipid Profiles in Experimental Rats

\begin{tabular}{|c|c|c|c|c|c|c|}
\hline Experimental Groups & Group I & Group II & Group III & Group IV & Group V & Group VI \\
\hline Glucose (mg/dl) & $\begin{array}{l}73.63 \\
\pm 1.90\end{array}$ & $\begin{array}{l}147.56 \\
\pm 2.55^{\#}\end{array}$ & $\begin{array}{r}127.27 \\
\pm 2.58\end{array}$ & $\begin{array}{r}109.88 \\
\pm 1.87\end{array}$ & $\begin{array}{l}97.59 \\
\pm 1.31 *\end{array}$ & $\begin{array}{l}73.59 \\
\pm 2.06^{* *}\end{array}$ \\
\hline Insulin ( $\mu l \mathrm{U} / \mathrm{ml})$ & $\begin{array}{l}3.55 \\
\pm 0.20\end{array}$ & $\begin{array}{l}7.20 \\
\pm 0.27^{\#}\end{array}$ & $\begin{array}{l}7.01 \\
\pm 0.39\end{array}$ & $\begin{array}{l}5.81 \\
\pm 0.27\end{array}$ & $\begin{array}{l}5.51 \\
\pm 0.30 *\end{array}$ & $\begin{array}{l}3.87 \\
\pm 0.27^{* *}\end{array}$ \\
\hline Leptin (ng/ml) & $\begin{array}{l}3.08 \\
\pm 0.24\end{array}$ & $\begin{array}{l}7.18 \\
\pm 0.32^{\#}\end{array}$ & $\begin{array}{l}6.71 \\
\pm 0.18\end{array}$ & $\begin{array}{l}5.97 \\
\pm 0.33\end{array}$ & $\begin{array}{l}5.23 \\
\pm 0.40^{*}\end{array}$ & $\begin{array}{l}3.15 \\
\pm 0.14^{* *}\end{array}$ \\
\hline TG (mg/dl) & $\begin{array}{l}67.75 \\
\pm 1.99\end{array}$ & $\begin{array}{l}163.83 \\
\pm 2.4^{\#}\end{array}$ & $\begin{array}{r}147.98 \\
\pm 1.99\end{array}$ & $\begin{array}{r}122.82 \\
\pm 1.47\end{array}$ & $\begin{array}{l}107.76 \\
\pm 1.57^{*}\end{array}$ & $\begin{array}{l}72.9 \\
\pm 0.97 * *\end{array}$ \\
\hline FFA (mg/dl) & $\begin{array}{l}22.92 \\
\pm 2.08\end{array}$ & $\begin{array}{l}43.71 \\
\pm 1.93^{\#}\end{array}$ & $\begin{array}{l}38.49 \\
\pm 2.40\end{array}$ & $\begin{array}{l}32.67 \\
\pm 1.84\end{array}$ & $\begin{array}{l}30.73 \\
\pm 1.31 *\end{array}$ & $\begin{array}{l}21.90 \\
\pm 1.03^{* *}\end{array}$ \\
\hline $\mathrm{TC}(\mathrm{mg} / \mathrm{dl})$ & $\begin{array}{l}98.02 \\
\pm 1.41\end{array}$ & $\begin{array}{l}194.16 \\
\pm 2.48^{\#}\end{array}$ & $\begin{array}{l}174.2 \\
\pm 2.63\end{array}$ & $\begin{array}{r}156.53 \\
\pm 1.69\end{array}$ & $\begin{array}{l}128.53 \\
\pm 1.66^{*}\end{array}$ & $\begin{array}{l}99.54 \\
\pm 1.59 * *\end{array}$ \\
\hline $\mathrm{HDL}-\mathrm{C}(\mathrm{mg} / \mathrm{dl})$ & $\begin{array}{l}61.28 \\
\pm 0.98\end{array}$ & $\begin{array}{l}38.45 \\
\pm 0.71^{\#}\end{array}$ & $\begin{array}{l}41.55 \\
\pm 1.12\end{array}$ & $\begin{array}{l}48.61 \\
\pm 1.28\end{array}$ & $\begin{array}{l}56.06 \\
\pm 0.84^{* *}\end{array}$ & $\begin{array}{l}58.99 \\
\pm 1.25^{* *}\end{array}$ \\
\hline LDL-C (mg/dl) & $\begin{array}{l}36.98 \\
\pm 0.65\end{array}$ & $\begin{array}{l}107.55 \\
\pm 1.43^{\#}\end{array}$ & $\begin{array}{l}92.3 \\
\pm 1.32\end{array}$ & $\begin{array}{l}77.84 \\
\pm 1.49\end{array}$ & $\begin{array}{l}61.44 \\
\pm 1.19 *\end{array}$ & $\begin{array}{l}37.71 \\
\pm 1.34^{* *}\end{array}$ \\
\hline VLDL-C (mg/dl) & $\begin{array}{l}17.55 \\
\pm 0.52\end{array}$ & $\begin{array}{l}34.76 \\
\pm 0.89^{\#}\end{array}$ & $\begin{array}{l}31.59 \\
\pm 1.28\end{array}$ & $\begin{array}{l}26.56 \\
\pm 0.69\end{array}$ & $\begin{array}{l}23.55 \\
\pm 0.95^{*}\end{array}$ & $\begin{array}{l}17.58 \\
\pm 0.59 * *\end{array}$ \\
\hline $\mathrm{Al}$ & $\begin{array}{l}1.62 \\
\pm 0.09\end{array}$ & $\begin{array}{l}5.08 \\
\pm 0.22^{\#}\end{array}$ & $\begin{array}{l}4.43 \\
\pm 0.24\end{array}$ & $\begin{array}{l}3.36 \\
\pm 0.29\end{array}$ & $\begin{array}{l}2.41 \\
\pm 0.25^{*}\end{array}$ & $\begin{array}{l}1.69 \\
\pm 0.13^{* *}\end{array}$ \\
\hline
\end{tabular}

Values are mean \pm S.E.M of 6 rats; ${ }^{\#} p<0.01$ vs Normal Control (Group I); ${ }^{*} p<0.05$ vs Obese Control (Group II); ${ }^{* *} p<0.01$ vs Obese Control (Group II) 
Table 4 Hepatic and Cardiac Triglyceride and Cholesterol Levels in Experimental Rats

\begin{tabular}{|c|c|c|c|c|}
\hline \multirow{2}{*}{$\begin{array}{l}\text { Experimental } \\
\text { Groups }\end{array}$} & \multicolumn{2}{|c|}{ Triglyceride (mg/g tissue) } & \multicolumn{2}{|c|}{ Total Cholesterol (mg/g tissue) } \\
\hline & Hepatic & Cardiac & Hepatic & Cardiac \\
\hline Group I & $10.52 \pm 0.42$ & $4.22 \pm 0.25$ & $5.35 \pm 0.22$ & $2.31 \pm 0.02$ \\
\hline Group ॥ & $17.72 \pm 0.39^{\#}$ & $8.35 \pm 0.43^{\#}$ & $10.13 \pm 0.42^{\#}$ & $4.83 \pm 0.06^{\#}$ \\
\hline Group III & $16.63 \pm 0.19$ & $8.08 \pm 0.21$ & $10.08 \pm 0.32$ & $4.51 \pm 0.05$ \\
\hline Group IV & $16.23 \pm 0.39$ & $7.62 \pm 0.41$ & $9.02 \pm 0.32$ & $4.12 \pm 0.12$ \\
\hline Group V & $15.13 \pm 0.65^{*}$ & $7.12 \pm 0.35^{*}$ & $8.14 \pm 0.35^{*}$ & $3.88 \pm 0.16^{*}$ \\
\hline Group VI & $10.42 \pm 0.23^{* *}$ & $4.51 \pm 0.31^{* *}$ & $5.58 \pm 0.29 * *$ & $2.28 \pm 0.09 * *$ \\
\hline
\end{tabular}

Values are mean \pm S.E.M of 6 rats; ${ }^{*} p<0.01$ vs Normal Control (Group I); ${ }^{*} p<0.05$ vs Obese Control (Group II); ${ }^{* *} p<0.01$ vs Obese Control (Group II)

oil in rats. The results (Fig. 3) showed that AEAA slightly reduced the elevation in plasma triacylglycerol levels after oral administration of a lipid emulsion.

A gain in body weight is a common index of obesity development [37]. In this study we found that HFD feeding resulted in approximately $15 \%$ more weight gain in the obese control rats when compared to normal control animals in a period of 60 days. This weight gain might be due to development of a positive energy balance on HFD feeding, leading to an increase in visceral fat deposition. It was found that the administration of AEAA along with HFD resulted in significant reduction $(p<$ 0.05) of weight gain in a dose dependent manner when compared to the HFD alone fed obese control rats (Fig. 5). These inhibitions in weight is not fully due to decreased food intake as there was not much difference in the amount of food consumed between the HFD (Group II) and AEAA treated groups (Group III to V) (Fig. 4). This reduction in body weight may partially be mediated via the inhibition of pancreatic lipase activity and via the activation of thermogenesis through the stimulation of the $\beta$-adrenergic receptors [38].

At the cell biological level, an important characteristic feature of obesity is increase in the number as well as size of adipocytes due to excessive fat deposition [39]. Thus, measuring the weight of these fat pads provide an insight about the severity of obesity. It was found that the weights of the mesenteric, retroperitoneal and perirenal adipose tissue deposits were significantly higher in the HFD fed rats than the normal diet fed rats. While, treatment with AEAA significantly $(p<0.05)$ reduced the weight of these fat pads when compared to that of HFD group. Furthermore, the measurement of the area of adipose cells after 9 weeks of administering AEAA along with a HFD showed that the plant extract suppressed the increases in the area of adipocytes in a dose dependent manner (Table 1, Fig. 7). Increase in organ weight can also be used as an index of obesity because intake of excess energy led to accumulation of extra energy in adipose tissues followed by accumulation in organs such as liver, kidney, heart and spleen [40]. HFD feeding to the experimental rats resulted in an increase in the weight of these organs by approximately $82 \%$, $64 \%, 66 \%$ and $80 \%$ respectively. However, administration of AEAA reduced the observed gain in organ weights in a dose dependent manner with the highest dose (300 $\mathrm{mg} / \mathrm{kg} \mathrm{bw}$ ) producing the maximum effect (Table 1).

BMI, a standard practical approach for assessing body fat provides a more accurate measure of total body fat as compared to the assessment of body weight alone [41]. But BMI is not a precise predictor of cardiovascular disease (CVD) although there is a correlation between

Table 5 Antioxidants Levels in Experimental Rats

\begin{tabular}{lllllll}
\hline Experimental Groups & Group I & Group II & Group III & Group IV & Group V & Group VI \\
\hline LPO (n Moles of MDA formed/g tissue) & 87.65 & 151.54 & 140.91 & 131.17 & 119.34 & 93.42 \\
& \pm 0.84 & $\pm 1.32^{\#}$ & \pm 1.39 & \pm 1.48 & $\pm 1.55^{*}$ & $\pm 1.20^{* *}$ \\
GSH (mg/g tissue) & 4.62 & 2.32 & 2.58 & 3.15 & 3.74 & 4.65 \\
& \pm 0.05 & $\pm 0.06^{\#}$ & \pm 0.02 & \pm 0.09 & $\pm 0.03^{*}$ & $\pm 0.08^{* *}$ \\
GPx ( $\mu$ Moles of GSH utilized/min/mg protein) & 3.42 & 1.08 & 1.64 & 2.11 & 2.45 & 3.37 \\
& \pm 0.11 & $\pm 0.02^{\#}$ & \pm 0.05 & \pm 0.02 & $\pm 0.08^{*}$ & $\pm 0.10^{* *}$ \\
SOD ( $\mu$ Moles of Epinephrine oxidized/mg protein) & 4.86 & 1.84 & 2.33 & 2.91 & 3.33 & 4.64 \\
& \pm 0.14 & $\pm 0.05^{\#}$ & \pm 0.06 & \pm 0.04 & $\pm 0.05^{*}$ & $\pm 0.16^{* *}$ \\
CAT ( $\mu$ Moles of $\mathrm{H}_{2} \mathrm{O}_{2}$ utilized/min/mg protein) & 31.10 & 13.29 & 16.42 & 19.90 & 23.38 & 30.67 \\
& \pm 1.09 & $\pm 0.53^{\#}$ & \pm 0.41 & \pm 0.43 & $\pm 1.02^{*}$ & $\pm 0.90^{* *}$ \\
\hline
\end{tabular}

Values are mean \pm S.E.M of 6 rats; ${ }^{*} p<0.01$ vs Normal Control (Group I); ${ }^{*} p<0.05$ vs Obese Control (Group II); ${ }^{* *} p<0.01$ vs Obese Control (Group II) 

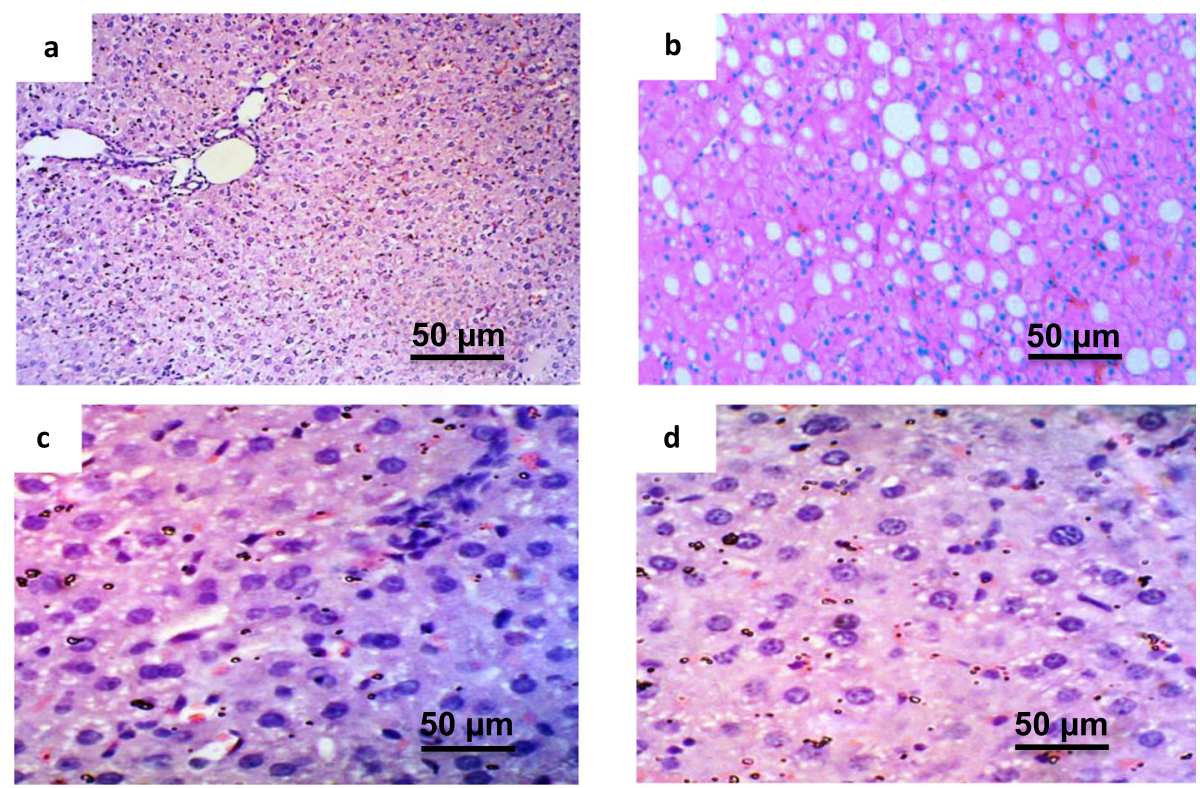

Fig. 6 Histology of liver tissue of experimental rats; a: Normal Diet fed rat liver without fatty droplets; b: HFD fed obese rat liver with larger fatty droplets; c: AEAA (300 mg/kg bw) treated obese rat liver with very few fatty droplets; d: Standard Drug (Orlistat) treated obese rat liver showing reduced fatty droplets

obesity and risk for cardiac disease. This makes measurement of BMI alone is insufficient for determining the risk of CVD. As excess abdominal fat will predispose obesity-related risk of CVD regardless of overall body fat, measuring waist circumference (WC) plays a critical role to assess obesity related cardiac risk. It has been reported that a reduction of $1 \mathrm{~cm}$ in the $\mathrm{WC}$ corresponds to a reduction of $1 \mathrm{~kg}$ of visceral fat. Moreover, it has also been reported that, if $\mathrm{WC}$ is increased by $1 \mathrm{~cm}$, the risk for the development of hypertension is increased by 2.49 times [42]. In the present study, the increased BMI and WC in HFD fed animals demonstrated the efficiency of HFD to induce obesity in these animals. However, the $\mathrm{BMI}$ and WC were reduced significantly $(p<0.05)$ on
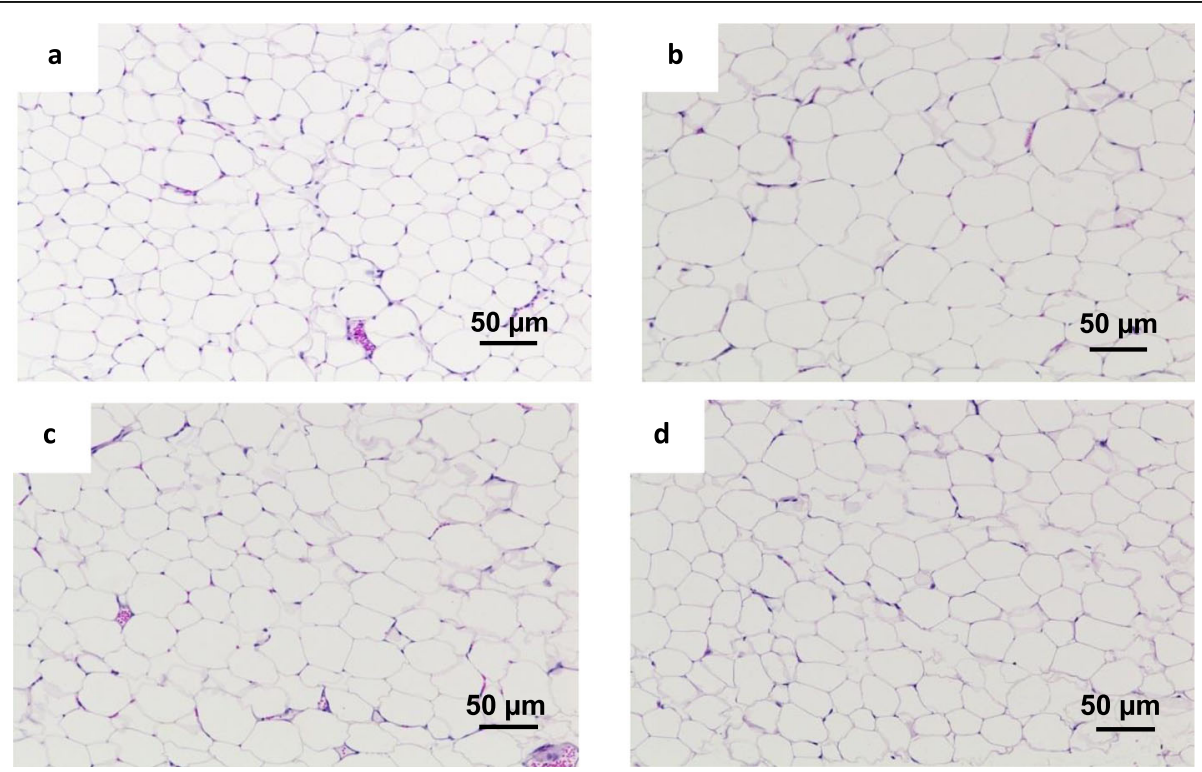

Fig. 7 Histology of epididymal adipose tissue of experimental rats; a: Normal Diet fed rat showing normal architecture of adipocytes; b: HFD fed obese rat showing increased size of adipocytes; c: AEAA (300 mg/kg bw) and $\mathbf{d}$ : Standard Drug (Orlistat) treated rat's adipocyte with decreased sizes 
treatment with AEAA in proportion to dose (Table 2). This reduction in BMI and WC indicated, decrement in fat accumulation as well as utilization of stored energy.

Overweight and obesity stands out the key triggers for insulin resistance (IR) and type 2 diabetes mellitus (T2DM) [43]. IR may develop due to alteration in the profile of bioactive substances called 'adipocytokines' (leptin, adiponectin, TNF- $\alpha$, IL- 6 etc.,) secreted by adipose tissue [44]. In the obese state, adipose tissue secretes proportionally more adipocytokines such as leptin, TNF- $\alpha$, IL- 6 etc., that may cause insulin resistance and fewer adipocytokines (eg., adiponectin) that is responsible for insulin sensitivity. Thus in obese condition due to insulin resistance glucose cannot be transported into the muscle or liver cells and leads to hyperglycemia. In responsive to hyperglycemia, pancreatic $\beta$-cells continually synthesize insulin which in turn leads to hyperinsulinemia. The results of present study also showed significant $(p<0.01)$ increase in the levels of serum glucose and insulin in HFD fed rats when compared to normal diet fed rats (Table 3). However, rats administered with AEAA along with HFD showed significant $(p<0.05)$ decrement in the levels of serum glucose and insulin in a dose dependent manner. As reported in earlier studies [45] this hypoglycemic and hypoinsulinemic effect may be mediated by the active phytoconstituents present in the test drug through the improvement of IR via increased adiponectin and reduced TNF- $\alpha$ secretion.

Leptin, the cytokine product of $o b$ gene, is synthesized and secreted mainly by adipose tissue in approximate proportion to fat stores [46]. Circulating leptin communicates the level of energy reserves in the periphery to the hypothalamus in order to suppress food intake and to permit energy expenditure. But elevated concentrations of endogenous leptin do not appear to do this role in obese condition due to leptin resistance [47]. Although the exact mechanism for leptin resistance or insensitivity is not fully understood, it has been suggested that elevated leptin levels in obesity may induce desensitization of the hypothalamic leptin receptors and thereby affects the neural networks downstream mediating leptin effects on energy intake and body weight [48]. In this study we observed that the serum leptin level in obese control group was raised to $7.18 \mathrm{ng} / \mathrm{ml}$ as compared to normal control animals $(3.08 \mathrm{ng} / \mathrm{ml})$. Administration of AEAA however, reduced the serum leptin level in a dose dependent manner (Table 3). This decrease in leptin level may be mediated through the lipid lowering activity of phytoconstituents present in the aqueous plant extract.

One of the main concerns of obesity is the presence of dyslipidaemia, since this significantly increases the risk of cardiovascular disease [49]. In terms of serum lipid profile in the present study, HFD significantly $(p<0.01)$ increased the levels of triglycerides (TG), free fatty acids (FFA), total cholesterol (TC), LDL-cholesterol (LDL-C), VLDL-cholesterol (VLDL-C) and decreased the levels of HDL-cholesterol (HDL-C) when compared with the normal group. Reduced levels of HDL-C are a major risk for coronary heart disease (CHD) independent of LDL and triglyceride levels. This risk is increased by the presence of high levels of LDL-C or increased TG [50]. In contrast, administration of AEAA along with HFD significantly $(p<0.05)$ inhibited the increases in the concentrations of TG, FFA, TC, LDL-C and VLDL-C in a dose dependent manner. The level of HDL-C was found to be elevated after treatment (Table 3). A substantial reduction in LDL-C and TC level in serum could be achieved by decreased production of cholesterol by liver tissue and/or efficient removal of the LDLcholesterol by various tissues without subsequent renewal [40]. Reductions in TC in serum may also be attributed to the effect of saponin which was reported to prevent micelles formation and subsequent reabsorption of cholesterol thereby increasing its excretion and depletion of body cholesterol [51]. Reductions in TG in serum may partially be associated with the inhibition of pancreatic lipase activity. A higher content of HDL-C observed in AEAA treated animal is a positive sign in decreasing the CHD risk, as it facilitates the transport of cholesterol from the serum to the liver, where it is catabolized and excreted from the body. The AI, defined as the ratio of TC and HDL-C, is believed to be an important risk factor of atherosclerosis. Our data clearly demonstrated that administration of AEAA significantly decreased the ratio through the elevation of $\mathrm{HDL}-\mathrm{C}$ concentration and decrement of TC (Table 3) thereby proving its antiatherogenic property.

Patients with obesity often develop liver steatosis, an increased build-up of fat in the liver. Although the pathogenesis of liver steatosis is unclear and multifactorial, it has been suggested that the presence of IR is an essential requirement for the accumulation of hepatocellular fat. IR results in enhanced rate of lipolysis in the adipose tissue, which in turn leads to an increased availability of free fatty acids responsible for an exaggerated synthesis and deposition of triglycerides in the hepatocytes [52]. Also, liver is the major contributor to the increased cholesterol production in obesity [53]. Our data indicated that intake of HFD for 9 weeks elevated the levels of hepatic TAGs and cholesterol indicating fatty liver. While, administration of AEAA along with HFD, ameliorated fatty liver by suppressing the elevated levels of hepatic TAG and cholesterol (Table 4). This result is well supported by the histopathological observation of liver tissues (Fig. 6). The lipid lowering actions of test drug may be due to increased expression of energy expenditure-related genes in liver 
and decreased fatty acid synthesis and fat intake in the liver. Intake of HFD for 9 weeks also elevated the levels of cardiac TAGs and cholesterol and this may be due to possibility of fat storage within the myocytes and fat deposition onto the coronary endothelium [54]. However, administration of AEAA along with HFD suppressed the increases in the levels of TAGs and cholesterol in the cardiac tissues (Table 4).

An elevated metabolism during obesity is associated with increased production of free radicals or reactive oxygen species (ROS). Whenever, the balance between ROS production and antioxidant defence is lost, this result in oxidative stress which lies at the baseline of many diseases. Chronic oxidative stress is one of the key mechanism underlying obesity-related morbidities [55]. Food or herb containing plenty of natural antioxidants is very important in the maintenance of health and in the prevention of many illnesses. In liver cells, increased rate of metabolism and accumulation of fat (fatty liver) during obesity leads to the generation of large amount of ROS which in turn is vulnerable to lipid peroxidation and oxidative stress. MDA, the product of lipid peroxidation, is an important marker for the level of oxygen free radicals. The content of MDA in rats fed with HFD was significantly higher in liver tissues as compared to rats fed with standard laboratory diet. Administration of AEAA prevented the HFD induced lipid peroxidation and resulted in a significantly decreased content of MDA in liver (Table 5).

Glutathione (GSH), a powerful antioxidant present within the cytosol, directly quenches ROS such as lipid peroxides and plays a major role against oxidative stress. The level of GSH in liver was significantly depleted in HFD fed animals when compared to normal control animals (Table 5). This depletion of GSH may be due to its utilization in large amounts to combat the HFD induced oxidative stress, as GSH is a major nonprotein thiol in living organisms playing a crucial role in coordinating the body's antioxidant defence processes [56]. In AEAA treated animals the level of GSH was significantly $(p<0.05)$ restored. Glutathione peroxidase (GPx) is one of the major peroxide scavenging enzymes and its activity is considered to represent the initial protective response required for adjusting the $\mathrm{H}_{2} \mathrm{O}_{2}$ concentration under normal physiological conditions as well as after oxidative insult. Optimum level of GSH is required in the body because GSH acts as a substrate for the detoxification of $\mathrm{H}_{2} \mathrm{O}_{2}$ by GPx [57]. In HFD fed obese rats, a fall in the activity of GPx was observed and this might be due to the depletion of GSH, as GSH is directly involving in quenching the ROS, Administration of AEAA effectively restored the activity of GPx and thereby decreased the production of hydroxyl radicals (Table 5).
During oxidative damage, superoxide radicals are generated at the site of damage. Cells have superoxide dismutase (SOD) and catalase (CAT) enzyme system to counteract these superoxide anions. SODs act as the first line of defence system against these superoxide anions and convert them into oxygen and hydrogen peroxide $\left(\mathrm{H}_{2} \mathrm{O}_{2}\right)$ while CAT converts these $\mathrm{H}_{2} \mathrm{O}_{2}$ to water and oxygen [58]. In the present study, the activities of SOD and CAT are decreased in HFD fed obese control rats as compared to normal control rats and this decrement might be due to generation of excessive free radicals and increased lipid peroxidation. The activities of SOD and CAT were restored in the test drug treated groups further suggesting the antioxidant potential of the test drug (Table 5). Restoration of the enzymatic and nonenzymatic antioxidant system might be due to the free radical scavenging activity of the phytoconstituents present in the test drugs such as flavones and alkaloids.

\section{Conclusion}

Altogether the obtained data clearly represented that the test drug, AEAA possess marked anti-obesity potential against HFD induced obese rats. It was observed that the test drug was more effective at the highest dose (300 $\mathrm{mg} / \mathrm{kg} \mathrm{bw}$ ) level. As observed in the present study, the anti-obesity potentials of AEAA might probably be mediated through delayed intestinal absorption of dietary fat due to the inhibition of pancreatic lipase activity, enhancement of antioxidant status mediated by the antioxidants such as flavones and regulation of fat metabolism. The current findings thus reinforce the scientific evidence for the anti-obesity potential of this plant used in traditional medicine.

\section{Abbreviations}

AEAA: Aqueous extract of aerial parts of Achyranthes aspera L.; HFD: High Fat Diet; CVD: Cardio Vascular Disease; BMI: Body Mass Index; WC: Waist Circumference; HDL-C: High Density Lipoprotein Cholesterol; LDL-C: Low Density Lipoprotein Cholesterol; VLDL-C: Very Low Density Lipoprotein Cholesterol; Al: Atherogenic index; TC: Total Cholesterol; TG: Triglycerides; FFA: Free Fatty Acids; LE: Lipid Emulsion; LPO: Lipid Peroxides; GSH: Reduced Glutathione; GPx: Glutathione Peroxidase; SOD: Superoxide Dismutase; CAT: Catalase; WAT: White Adipose Tissue; IR: Insulin Resistance;

ROS: Reactive Oxygen Species; MDA: Malondialdehyde; $I C_{50}$ : Inhibitory Concentration 50

\section{Acknowledgements}

The authors are grateful to Sri Ranga Ramanuja Centre for Advanced Research in Sciences (SRRCARS), Srimad Andavan Arts and Science College (Autonomous), Trichy, India for providing Animal House and Laboratory facilities. Authors also extend their gratefulness to SASTRA University, Thanjavur, India for providing instrumental facilities to analyse adipocyte size.

\section{Authors' contributions}

All authors strived to accomplish the present work, from the experiments to the manuscript. Athesh Kumaraswamy conducted all the pharmacological assays, literature search and manuscript preparation; Sivasubramanian Rangarajan supported in animal maintenance and experiments; Jothi Gnanasekaran did relevant interpretation of the results; Brindha Pemiah designed, supervised the experiments and reviewed the manuscript. The author(s) read and approved the final manuscript. 


\section{Funding}

None.

\section{Availability of data and materials}

All the necessary data and materials are included in the article.

\section{Ethics approval and consent to participate}

All the studies were conducted according to the ethical guidelines of 'the committee for the purpose of control and supervision of experiments on animals' (CPCSEA) after getting necessary clearance from the committee (Approval No: 790/03/ac/CPCSEA).

\section{Consent for publication}

The authors permitted to publish this work in Clinical Phytoscience.

\section{Competing interests}

The authors declare that there is no conflict of interests regarding the publication of this article.

\section{Author details}

'PG \& Research Department of Biochemistry, Srimad Andavan Arts and Science College (Autonomous), Affiliated to Bharathidasan University, Tiruchirappalli, Tamil Nadu 620 005, India. ${ }^{2}$ The Centre for Advanced Research in Indian Systems of Medicine (CARISM), SASTRA University, Thanjavur, Tamil Nadu 613 401, India.

Received: 1 June 2020 Accepted: 3 November 2020

Published online: 07 November 2020

\section{References}

1. WHO. Physical status: the use and interpretation of anthropometry. Report of a WHO Expert Committee. Geneva, World Health Organization, (Technical Report Series, No. 854), 1995:329.

2. Chooi YC, Ding C, Magkos F. The epidemiology of obesity. Metabolism. 2019;92:6-10.

3. Imaz I, Martinez-Cervell C, Garcia-Alvarez EE, Sendra-Gutierrez JM, GonzalezEnriquez J. Safety and effectiveness of the intragastric balloon for obesity- a meta-analysis. Obes Surg. 2008;18(7):841-6.

4. Susan Z, Yanovski MD, Jack A, Yanovski J. Long-term drug treatment for obesity: a systematic and clinical review. JAMA. 2014;311(1):74-86.

5. Hatahet MA, Dhurandhar NV. Antiobesity drugs: current and future issues. Curr Diab Rep. 2002;2(5):409-15.

6. Bhoomika RG, Ramesh KG, Anita AM. Phyto-pharmacology of Achyranthes aspera - a review. Phcog Rev. 2007;1(1):143-50

7. Varuna KM, Khan MU, Sharma PK. Review on Achyranthes Aspera. J Pharm Res. 2010;3(4):714-7.

8. Gamble JS. Flora of presidency of Madras, botanical survey of India. Vol II: 1997. p. 665-7.

9. Vidhya R, Rajiv Gandhi G, Jothi G, Radhika J, Brindha P. Evaluation of antidiabetic potential of achyranthes aspera Linn. On alloxan induced diabetic animals. Int J Pharm Pharm Sci. 2012;4:577-80.

10. Xu BJ, Han LK, Zheng YN, Lee JH, Sung CK. In-Vitro inhibitory effect of Triterpenoidal Saponins from Platycodi Radix on pancreatic lipase. Arch Pharm Res. 2005:28(2):180-5.

11. Han LK, Kimura Y, Kawashima M, Takaku T, Taniyama T, Hayashi T, Zheng YN, Okuda $\mathrm{H}$. Anti-obesity effects in rodents of dietary teasaponin, a lipase inhibitor. Int J Obes. 2001;25:1459-64.

12. Buettner R, Scholmerich J, Bollheimer LC. High-fat diets: modeling the metabolic disorders of human obesity in rodents. Obesity (Silver Spring) 2007;15:798-808.

13. Matsuia N, Itoa R, Nishimura E, Yoshikawaa M, Kato M, Kamei M, Shibatab H, Matsumoto I, Abe K, Hashizume S. Ingested cocoa can prevent high fat diet-induced obesity by regulating the expression of genes for fatty acid metabolism. Nutrition. 2005:21:594-601.

14. Jang WS, Choung SY. Antiobesity effects of the ethanol extract of Laminaria japonica Areshoung in high-fat-diet-induced obese rat. Evid Based Complement Alternat Med. 2013. https://doi.org/10.1155/2013/492807.

15. Bhosale UA, Yegnanarayan R, Pophale P, Somani R. Effect of aqueous extracts of Achyranthes aspera Linn. On experimental animal model for inflammation. Anc Sci Life. 2012;31(4):202-6.
16. Lemaure B, Touche A, Zbinden I, Moulin J, Courtois D, Mace K, Darimont C. Administration of Cyperus rotundus tubers extract prevents weight gain in obese Zucker rats. Phytother Res. 2007;21:724-30.

17. Yang C, Li L, Yang L. Lu H, Wang S, Sun G. Anti-obesity and Hypolipidemic effects of garlic oil and onion oil in rats fed a high-fat diet. Nutr Metab 2018;15:43.

18. Hsu CL, Yen GC. Effect of gallic acid on high fat diet-induced dyslipidaemia, hepatosteatosis and oxidative stress in rats. Br J Nutr. 2007:98(4):727-35.

19. Novelli ELB, Diniz YS, Galhardi CM, Ebaid GMX, Rodrigues HG, Mani F, Fernandes AAH, Cicogna A, Novelli Filho JLVB. Anthropometrical parameters and markers of obesity in rats. Lab Anim. 2007:41(1):111-9.

20. Folin O, Wu H. A system of blood analysis. J Biol Chem. 1919;38:81-110.

21. Finlay JW, Dillard RF. Appropriate calibration curve fitting in ligand binding assays. APPS J. 2007;9(2):E260-7.

22. Considine RV, Sinha MK, Heiman ML, Kriaciunas A, Stephens TW, Nyce MR, Ohannesian JP, Marco CC, McKee LJ, Bauer TL, Cara JF. Serum mmunoreactive leptin concentraions in normal-weight and obese humans. N Engl J Med. 1996;334:292-5.

23. Foster LB, Dunn RT. Stable reagents for determination of serum triglycerides by a colorimetric Hantzsch condensation method. Clin Chem. 1973;19(3):338-40.

24. Falholt $K$, Lund B, Falholt W. An easy colorimetric method for routine determination of free fatty acids in plasma. Clin Chim Acta. 1973:46(2):105-11.

25. Parekh AC, Jung DH. Determination of cholesterol with ferric acetate, uranium acetate and sulphuric acid-ferrous sulphate reagents. Anal Chem. 1970:42:1523-9.

26. Friedewald WT, Levy RI, Fredrickson DS. Estimation of the concentration of low density lipoprotein cholesterol in plasma, without use of the preparative ultracentrifuge. Clin Chem. 1972;18(6):499-502.

27. Ohkawa H, Ohishi N, Yagi K. Assay of lipid peroxides in animal tissues for thiobarbituric acid reaction. Anal Biochem. 1979;95(2):351-8.

28. Moron MS, Depierre JW, Mannervik B. Levels of glutathione, glutathione reductase and glutathione-S-transferase activities in rat lung and liver. Biochem and Biophys Acta. 1979;5820:60-8.

29. Rotruck JT, Pope AL, Ganther H, Swanson AB, Hafeman DG, Hoeksira WG. Selenium: biochemical role as a component of glutathione peroxidase. Science. 1790;1973:588-90.

30. Misra HP. Fridovich I. The role of superoxide anion in the autooxidation of epinephrine and a simple assay for SOD. J Biol Chem. 1972;247:3170-5.

31. Maehly AC, Chance B. In: methods of biochemical analysis, Vol. I, Glick D, editors, New York, Interscience. 1954;357.

32. Vijaya C, Ramanathan M, Suresh B. Lipid lowering activity of ethanolic extract of leaves of Aegle marmelos (Linn.) in hyperlipidaemic models of Wistar albino rats. Indian J Experimental Biol. 2009;47:182-5.

33. Kusunoki M, Hara T, Tsutsumi K, Nakamura T, Miyata T, Sakakibara F, Sakamoto S, Ogawa H, Nakaya Y, Storlien LH. The lipoprotein lipase activator, NO-1886, suppresses fat accumulation and insulin resistance in rats fed a high-fat diet. Diabetologia. 2000;43:875-80.

34. Verger R. Pancreatic lipase. In: Borgstrom B, Brockman HL, editors. Lipase. Elsevier: Amsterdam; 1984. p. 83-150

35. Drent ML, Popp-Snijders C, Ader HJ, Jansen JB, van der Veen EA. Lipase inhibition and hormonal status, body composition and gastrointestinal processing of a liquid high-fat mixed meal in moderately obese subjects. Obes Res. 1995;3:573-81.

36. Filippatos T, Derdemezis C, Gazi I, Nakou E, Mikhailidis D, Elisaf M. Orlistatassociated adverse effects and drug interactions: a critical review. Drug Saf. 2008;31:53-65.

37. Van der Ploeg LH. Obesity: an epidemic in need of therapeutics. Curr Opin Chem Biol. 2000;4(4):452-60.

38. Preuss HG, DiFerdinando D, Bagchi M, Bagchi D. Citrus aurantium as a thermogenic, weight-reduction replacement for ephedra: an overview. J Med. 2002:33:247-64.

39. Furuyashiki T, Nagayasu H, Aoki Y, Bessho H, Hashimoto T, Kanazawa K, Ashida $\mathrm{H}$. Tea catechin suppresses adipocyte differentiation accompanied by down-regulation of PPARgamma2 and C/EBPalpha in 3T3-L1 cells. Biosci Biotechnol Biochem. 2004:68:2353-9.

40. Kang M, Oh JW, Lee HK, Chung HS, Lee SM, Kim C, Lee HJ, Yoon DW, Choi H, Kim H, Shin M, Hong M, Bae H. Anti-obesity effect of PM-F2-OB, an anti-obesity herbal formulation, on rats fed a high-fat diet. Biol Pharm Bull. 2004;27(8):1251-6.

41. Heymsfield SB, Allison DB, Heshka S, Pierson RN. Assessment of human body composition. In: Allison DB, editor. Handbook of assessment methods 
for eating behaviors and weight related problems: measures, theory, and research. Thousand Oaks, CA: Sage Publications; 1995. p. 515-60.

42. Michishita T, Kobayashi S, Katsuya T, Ogihara T, Kawabuchi K. Evaluation of the Antiobesity effects of an amino acid mixture and conjugated linoleic acid on exercising healthy overweight humans: a randomized, double-blind, Placebo-controlled Trial. J Int Med Res. 2010;38:844-59.

43. Yaturu S. Obesity and type 2 diabetes. J Diabetes Mellitus. 2011;1:79-95.

44. Matsuzawa Y. The metabolic syndrome and adipocytokines. FEBS. 2006;580: 2917-21.

45. Francini-Pesenti F, Spinella P, Calò LA. Potential role of phytochemicals in metabolic syndrome prevention and therapy. Diabetes Metab Syndr Obes. 2019;12:1987-2002.

46. Minocci A, Savia G, Lucantoni R, Berselli ME, Tagliaferri M, Calo G, Petroni ML, de Medici C, Viberti GC, Liuzzi A. Leptin plasma concentrations are dependent on body fat distribution in obese patients. Int J Obes. 2000;24: 1139-44.

47. Considine RV, Caro JF. Leptin and the regulation of body weight. Int J Biochem Cell Biol. 1997;29:1255-72.

48. Lin S, Thomas TC, Storlien LH, Huang XF. Development of high fat dietinduced obesity and leptin resistance in C57Bl=6J mice. Int J Obes. 2000;24: 639-46.

49. Martins JM, Carreiras F, Falcao J, Afonso A, da Costa JC. Dyslipidaemia in female overweight and obese patients. Relation to anthropometric and endocrine factors. Int J Obes. 1998;22:164-70.

50. Young CE, Karas RH, Kuvin JT. High-density lipoprotein cholesterol and coronary heart disease. Cardiol Rev. 2004;12(2):107-19.

51. Zhao HL, Sim JS, Shim SH, Ha YW, Kang SS, Kim YS. Antiobese and hypolipidemic effects of platycodin saponins in diet-induced obese rats: evidences for lipase inhibition and calorie intake restriction. Inter J Obes 2005;29:983-90.

52. Luyckx FH, Desaive C, Thiry A, Dewe W, Scheen AJ, Gielen JE, Lefebvre PJ. Liver abnormalities in severely obese subjects: effect of drastic weight loss after gastroplasty. Int J Obes. 1998;22:222-6.

53. Leijd B. Cholesterol and bile acid metabolism in obesity. Clin Sci. 1980;59: 203-6.

54. Vincent HK, Powers SK, Dirks AJ, Scarpace PJ. Mechanism for obesity - induced increase in myocardial lipid peroxidation. Int J Obes. 2001;25:378-88.

55. Vincent HK, Taylor AG. Biomarkers and potential mechanisms of obesity induced oxidant stress in humans. Int J Obes. 2006;30:400-1.

56. Joy J, Nair CK. Amelioration of cisplatin induced nephrotoxicity in swiss albino mice by Rubia cordifolia extract. J Cancer Res Ther. 2008;4(3):111-5.

57. Lee YS, Kim AY, Choi JW, Kim M, Yasue S, Son HJ, Masuzaki H, Park KS, Kim JB. Dysregulation of adipose glutathione peroxidase 3 in obesity contributes to local and systemic oxidative stress. Mol Endocrinol. 2008;22(9):2176-89.

58. Erdeve O, Siklar Z, Kocaturk PA, Dallar Y. Antioxidant superoxide dismutase activity in obese children. Biol Trace Elem Res. 2004;98(3):219-28.

\section{Publisher's Note}

Springer Nature remains neutral with regard to jurisdictional claims in published maps and institutional affiliations.

\section{Submit your manuscript to a SpringerOpen ${ }^{\circ}$ journal and benefit from:}

- Convenient online submission

- Rigorous peer review

- Open access: articles freely available online

- High visibility within the field

- Retaining the copyright to your article

Submit your next manuscript at $\boldsymbol{\nabla}$ springeropen.com 